\title{
Feedlot operation problems from floods in southern Alberta: a Canadian case study
}

\author{
M. P. Acharya ${ }^{1}$, R. G. Kalischuk ${ }^{1}$, K. K. Klein ${ }^{1} \&$ H. Bjornlund ${ }^{1,2}$ \\ ${ }^{I}$ Department of Economics and School of Health Sciences, \\ University of Lethbridge, Canada \\ ${ }^{2}$ University of South Australia, Adelaide, Australia
}

\begin{abstract}
In the summer of 2005, southern Alberta received the heaviest precipitation in the region's history. Heavy and persistent rains during June and September triggered heavy flooding in Oldman River basin, the principal source of water used in nine of thirteen irrigation districts of southern Alberta. In the fall of 2005, a flood impact survey of feedlot farm families was conducted in the Lethbridge Northern Irrigation District (LNID). The objectives of the survey were to determine the types of feedlot operation problems the farm families encountered during the flooding, their responses to the immediate problems, and their plans to reduce future risks. The analyses revealed that most experienced major flood-related problems on their farm operations. For instance, 97\% reported problems associated with feedlot and flood runoff management, animal health and performance, and damages to feed and storage facilities. To reduce the effects of excess contaminated water, a vast majority (85\%) of respondents reported that they sprayed contaminated floodwater onto their cropland. A majority $(82 \%)$ of the respondents treated their sick animals themselves and $39 \%$ said that they have no future flood risk reduction plans for their farm operations. However, the majority of them do have plans for reducing the impacts of future floods, to protect the water quality, the health of their animals and their livelihood.

Keywords: flooding, farm families, feedlot operation problems, southern Alberta, Canada, Oldman River basin, floodwater management strategies, flood risk reduction plans, water contamination.
\end{abstract}




\section{Introduction}

The year 2005 was the wettest and costliest year in several decades for the southern part of the province of Alberta in Canada [1, 2]. Four major summer flood events (three in June and one in September) in 2005 made that year the costliest natural disaster in the region's weather history [1, 3]. Unprecedented rain events in early June (6-9) brought precipitation throughout much of southern Alberta with a total accumulation more than $220 \mathrm{~mm}$ (not including the spring snow melt) [4, 5]. In communities such as Granum, Claresholm and Pincher Creek, the total accumulation during this period reached more than $240 \mathrm{~mm} \mathrm{[6]}$ causing overland flooding, destroying businesses, homes and public facilities, and severely harming farm and livestock operations, especially CLOs [4-8]. Further precipitation on June 19 produced up to $175 \mathrm{~mm}[3,6]$ of rain alone in southern Alberta [2, 3]. This one day rain event caused all major rivers, including the Oldman River basin, the main source of water used by nine of the thirteen irrigation districts and people residing in southern Alberta, to overflow [9]. According to reports, officials described this June flooding as a "one-in200-year event" [3] and, combined with the September 9-11 rainstorms, produced a total summer precipitation accumulation of $534 \mathrm{~mm}[8,10]$.

It is estimated that over $\$ 1$ billion in federal, provincial and local funds were spent helping southern Alberta communities and agricultural interests recover from the 2005 summer flooding. The Government of Alberta established the Southern Alberta Disaster Recovery Program (SADRP), the largest disaster financial assistance program of its kind in the province's history to help flood affected people, particularly for damages which insurance was not readily and reasonably available [11]. Besides the provincial government's SADRP payment of $\$ 73.1$ million [10], the Government of Canada has paid a total of $\$ 49$ million in two instalments under the Disaster Financial Assistance (DFA) to assist the province with response and recovery cost $[12,13]$. The federal government also accelerated the payout of agricultural disaster assistance of \$755 million under the Grains and Oilseeds Payment Program to the farmers of Alberta who were facing economic strain from both rising input costs and low grain prices along with the difficulties in the growing summer condition of 2005 [14].

This region, which normally is moisture deficit, covers more than $114,000 \mathrm{sq}$ $\mathrm{km}$ and is home to half of Alberta's population of over 3.3 million [15] and over 11 million livestock [16]. Dry land farming in most of this region, combined with an elaborate field crop irrigation system, an expanding food processing and livestock industries, particularly confined livestock operations (CLOs), has made agriculture the dominant force in the regional economy [15].

The 2005 floods created public concerns about the safety and quality of water, as well as worries about the feedlot industry in and around southern Alberta. The purpose of this study was to determine the problems faced by farm feedlot operation operations in this area as well as the impacts the floods had on their families [7, 8]. A flood impact survey of farm feedlot operators and their families in the Lethbridge Northern Irrigation District (LNID) was conducted in 
the fall of 2005. The objectives of this survey were to: (1) determine the types of feedlot operation problems experienced by the farm families from the 2005 floods; (2) determine their responses to the feedlot operation problems during flooding; and (3) identify and analyze plans for minimizing the risk of future flooding.

\section{Study site description}

The research was undertaken within the Lethbridge Northern Irrigation District, which takes water mostly from the Oldman River basin, a supplier for nearly half of the 1.2 million acres of irrigated land in Alberta [9]. This district is situated on the south western part of Alberta and covers about 93,100 ha of land on the north side of the Oldman River [16]. Its distribution system is $650 \mathrm{~km} \mathrm{[17]} \mathrm{in}$ length and supplies irrigation water to over 52,600 ha of cultivated lands, pastures and feedlot farm dugouts through diked and mostly lined open canals and pipelines [18]. Because of its well advanced irrigation system, the district has fostered growth in both the cattle and food processing industries [7, 8].

LNID is home to 80 beef feedlot operators, almost half of whom are large in scale. This area is sometimes called "Feedlot Alley" $[19,20]$ because more than one third of the province's cattle are fed and finished in this small geographical region. Several feedlots feed more than 25,000 cattle at one time [19]. The sheer size of these operations has raised questions about environment, water quality and threats to public health $[17,20]$. Alberta's Chinook Regional Health Region reported that this area is plagued by chronic health problems and water quality concerns [21, 22]. Recent research also suggests that fecal coliform bacteria levels in the Oldman River basin occasionally exceed Canadian Water Quality Guidelines for human consumption [18, 21, 22].

\section{Methods}

A questionnaire was developed to provide data on farm operation and health problems experienced by the feedlot farm families, actions associated with particular flood events, and resources that were found to be most and least helpful for dealing with flood-related problems [7, 8]. Also, questions were asked that pertained to future plans that could minimize the impacts of future flooding on their farm operations. Finally, demographic and farm specific questions (e.g., gender, age, marital status, education, place of birth, family composition, employment status, size and type of farming operation, number of animals fed per year) and source(s) of water for their farmstead and waste management practices were included.

Following review by the general manager of the LNID and pre-testing of the questionnaire, an in-person survey was carried out in the fall of 2005 [9]. All feedlot families on a list provided by the staff of LNID (containing 64 potential respondents) were contacted and asked if they would participate in the study. Four duplicate names were removed from this prepared list. Data were collected from all who consented to the survey: a total of 33 feedlot owners and/or 
employees between the ages of 27 and 70. The interviews averaged between 1 and 2 hours in length. All interviews were coded into an Excel spreadsheet for frequency distributions of variables, and analyses of the respondents' 2005 flood-related farm operation problems, concerns and management practices.

\section{Results}

\subsection{Feedlot operation problems experienced during flooding}

The respondents were asked to describe the types of problems they experienced in their homes and farm operations during heavy rainfall in the months of June and September. A minority of feedlot farm families $(20 \%)$ experienced severe residential damages and problems with domestic water supplies and sewage systems.

Table 1: $\quad$ Percent and types of feedlot problems respondents experienced during the floods of 2005.

\begin{tabular}{|l|c|}
\hline \multicolumn{1}{|c|}{ Types of Problems } & Respondents \\
\hline \multicolumn{1}{|c|}{ Experienced } & $\%$ Indicated \\
\hline Wastewater \& Flood Runoff Management & 97 \\
-Pen Problems (i.e. overflow, messy, damaged, etc.) & 91 \\
-Lagoon Overflow & 88 \\
-Access & 88 \\
-Equipment problems (i.e. destroyed from the flood, not & \\
available or accessible) & 88 \\
-Drainage Problem & 79 \\
-Lagoon Full & \\
\hline Animal Health, Illness \& Death & 97 \\
-Animal Illness (primarily foot rot) & 97 \\
-Animal Performance & 67 \\
-Loss of Animal & 94 \\
\hline Animal Feed \& Bedding Supplies & 85 \\
-Crop Damage (i.e. forages) & 79 \\
\hline -Animal Feed loss & 70 \\
\hline -Grain loss & 94 \\
\hline Labour Issues & \\
\hline Damages to Storage \& Office Space & \\
\hline
\end{tabular}

Most feedlot operators in the LNID had cattle in their feedlots at the time of the floods so the events had a huge bearing on their farm operations. All respondents admitted that the floods severely and extensively damaged their farm operations. For example, they discussed how the floods damaged their pens, caused their lagoons to overflow (91\%), and blocked effluent drainage systems (88\%) (Table 1). Persistent torrential rainfall made it difficult for most 
to access and clean pens (88\%). Many experienced structural damages to pens and liquid waste management system. Many reported reductions in animal performance because of flood-related illnesses and reduced feed intakes. Loss of grain, crop damage, loss of bedding supplies and damages to storage and office space also were reported. The majority of the respondents were worried about financial losses, and most were unable to estimate the value of their losses.

\subsection{Responses to the feedlot operation problems during flooding}

Table 2 outlines the most important measures that respondents used to manage flood-related farm operation problems. It is clear from the data that during the floods, pumping contaminated water from lagoons and pens was the most common measure used, followed by cleaning and rebuilding pens and treating sick animals. Though all respondents were knowledgeable about the public

Table 2: $\quad$ Responses to the feedlot operation problems during the floods of 2005.

\begin{tabular}{|l|c|l|c|}
\hline Measures & Respondents & Measures & Respondents \\
\hline Used & $\%$ indicated & Used & $\%$ indicated \\
\hline Wastewater and Flood Runoff & & Animal Treatments & \\
Management & & - Professional & 0 \\
-Pumped lagoon(s) & 91 & - Self & 82 \\
-Cleaned pen(s) & 91 & - Animal feed and & 6 \\
-Rebuild pen(s) & 88 & & \\
-Pumped out pen water & & & \\
-Evacuated the animals from & 64 & & \\
the pen(s) & 9 & & \\
-Build/rebuild lagoon(s) & 9 & & \\
-Enlarged lagoon(s) & & Equipment & \\
\hline Disposal of Wastewater & 85 & - Rented & \\
- Lagoon water onto the field & & - Purchased & \\
- Pen water & 76 & & \\
- Field & 3 & & \\
- County ditch & 3 & & \\
- Professional cleaner & 12 & & \\
- Other (e.g., irrigation canal, & & & \\
hill top and/or hay stack) & 6 & & \\
\hline Equipment Used to Dispose & & & \\
Wastewater & 70 & & \\
- Sprinkler/pivot & 6 & & \\
- Slurry wagon & & & \\
- Hand mover & & & \\
- Professional cleaner & & \\
- Other (e.g., floating pump, & & \\
etc.) & & & \\
\hline
\end{tabular}


health hazards of spraying concentrated fecal wastes from intensive livestock operation pits onto crop fields [7, 8, 23, 24], many (70\%) admitted disposing contaminated water from their feedlot facilities through sprinkler/pivot systems onto the fields and 64\% removed animals from flooded pens. Only 3\% used professional cleaners to dispose of contaminated floodwater from their farm operations.

\subsection{Plans for minimizing the risk of future feedlot operation flooding}

When assessing what measures respondents planned to undertake to minimize future flood-related farm damages, $39 \%$ of the respondents indicated that they had no plans to make any changes to their farm operations (Table 3). Those individuals strongly believed that floods vary greatly in their character and it therefore is impossible to be ready for such disasters. In contrast, $27 \%$ said that they will expand their lagoons, about one quarter (24\%) plan to add additional drainage systems, $21 \%$ intend to work in collaboration with the LNID, county of Lethbridge, and other non-governmental agencies to prevent and control wastewater runoff, and 15\% said they will landscape their yard to divert flood runoff away from their farmsteads.

Table 3: Measures that respondents plan to undertake to minimize future damages to their feedlot operations from floods.

\begin{tabular}{|l|c|}
\hline \multicolumn{1}{|c|}{ Types of measures } & Respondents \\
\hline \multicolumn{1}{|c|}{ Planned } & $\%$ indicated \\
\hline Nothing & 39 \\
\hline Expand lagoon(s) & 27 \\
\hline Add drainage systems & 24 \\
\hline $\begin{array}{l}\text { Joint project with LNID, County of Lethbridge and } \\
\text { others to prevent and control wastewater runoff }\end{array}$ & 21 \\
\hline Landscape & 15 \\
\hline Build storage for animal feed & 6 \\
\hline Build berms & 6 \\
\hline Regular maintenance & 6 \\
\hline Build a new feedlot & 3 \\
\hline
\end{tabular}

\section{Discussion}

In 2005, southern Alberta experienced heavy rain events as well as localized thunderstorms making it one of the worst flooding years in the province's history. Consequently, farm families in the LNID encountered serious problems in their feedlot operations despite following, for the most part, the Alberta government's livestock operation guidelines [25], and beneficial management practices [26]. Besides the effects of inundation and damage to fecal waste pits, LNID feedlots experienced significant problems in the management of floodwater runoff, 
breaching of lagoons and pens, animal health and animal feed. For example, 67\% of the respondents reported losing animals from flooded pens [23] (Table 1). To make the situation worse, several encountered challenges in hiring extra workers and renting equipment during the flood cleanup. While all respondents were aware of the negative impacts of contaminated lagoon water on crop agriculture, most acknowledged spraying this contaminated lagoon water onto cropland as a solution to protect their animals and their businesses. This type of feedlot waste management practice raises new concerns about flood-related dispersion of livestock wastes because of its deleterious effects on soil and runoff water as well as on public health $[13,18,23,24]$. It also suggests that service providers should consider evaluating the floodwater dispersion system of the region.

Although the farm feedlot operators who were surveyed lived in an area that contains several intensive livestock operations and were exposed to contaminated water while cleaning pens and engaging in other farm activities, they reported relatively low levels of immediate, short- or long-term infectious disease effects or occurrences of clinically related pathologies. Unlike some flood-related health issues noted in other studies [8, 21, 24], none of the affected feedlot farmers in this study mentioned injuries during flood or clean-up activities. Also, contamination of sources of water supplies for the livestock watering was not a major concern of the farm families who responded to the survey. All indicated that they turned off their water intake from irrigation canals as a preventative measure to avoid possible contamination of their reservoir water.

It is evident from the analysis that a majority of feedlot operators in this region have plans for reducing the impact of future floods, to protect the water quality, health of their animals and their livelihood. The major policy implication from this research is that authorities should work in collaboration with flood affected residents and rural communities to improve existing provincial flood disaster programs and livestock waste management policies and regulations so that negative economic impacts of this type of natural disaster can be mitigated. Also, the efficiency and effectiveness of the infrastructure for disposal of farm wastewater, particularly storm water drainage systems, needs to be further assessed to protect livestock farmers and their operations from future flooding.

\section{Acknowledgements}

The authors thank the Alberta Ingenuity Centre for Water Research (AIWRC) for the financial support to carry out this research and the LNID office for providing the contact information of the feedlot farm families. We also thank all the respondents who gracefully and freely shared their experiences with the interviewer.

\section{References}

[1] World Meteorological Organization, WMO statement on the status of the global climate in 2005, World Meteorological Organization, Geneva, Switzerland, 2005. 
[2] Canadian Broadcasting Corporation, 2005 sets rain and flood records, 2005, CBC News, www.cbc.ca/canada/story/2005/12/29/weatherrecords051229.html.

[3] Carpenter, G., Floods in Alberta, Reported date, $30^{\text {th }}$ June 2005.

[4] Alberta Environment, Weather conditions, 2005. http:/www.3.gov.ab.ca/env/water/kbasins/basinform.cfm.

[5] Gauntlett, K., Floods force alert, evacuations across southern Alberta, Calgary Herald, Tuesday, June 07, 2005.

[6] Alberta Environment, June 2005 flood events in Alberta. Presentation to the Alberta Environment Conference, 2006.

[7] Acharya, M. P., Grant Kalischuk, R. Klein, K. K. \& Bjronlund, H., Do water contamination reports influence water use practices on feedlot farms and rural households in southern Alberta? Canadian Water Resources Journal, 32, pp. 1-14, 2007a.

[8] Acharya, M. P., Grant Kalischuk, R. Klein, K. K. \& Bjronlund, H., Health impacts of the 2005 flood events on feedlot farm families in southern Alberta, Canada, WIT Transactions on Ecology and the Environment, 103, $2007 b$.

[9] Johnston, A., Floods in the Oldman river valley at Lethbridge, Sir Alexander Galt Museum, Lethbridge, Alberta, 1989.

[10] Alberta Municipal Affairs, Flooding in Alberta in 2005 - An overview, Alberta Municipal Affairs, Edmonton, 2006.

[11] Government of Alberta, Province approves disaster recovery program for southern Alberta, News Release, February 8, 2006.

[12] Public Safety and Emergency Preparedness Canada, Canada's new government provides over $\$ 24$ million to assist Alberta with flood recovery, Ottawa, 03-01-2007a.

[13] Public Safety and Emergency Preparedness Canada, Minister Day announces \$25 million in Alberta for recovery assistance, Ottawa, 02-112007b.

[14] Alberta Agriculture and Food, 2006 Agricultural Service Board Resolutions, Edmonton, Alberta, 2008. http://agric.gov.ab.ca/\$Department/deptdocs.nsf/all/rsv10532

[15] Government of Alberta, Environment: Southern region, see http://environment.alberta.ca/1813.html, 13-02-2008.

[16] Statistics Canada, Livestock estimates, Prepared by Statistics and Data Development Unit, Alberta Agriculture, Food and Rural Development, Edmonton, Alberta, 2001.

[17] Alberta Irrigation Projects Association, Irrigation in the $21^{\text {st }}$ century. Volume 1: Summary report, Alberta Irrigation Association, Lethbridge, AB, 2002.

[18] Saffran, K. A., Oldman river basin water quality initiative surface water quality summary report, Oldman River Basin Water Quality Initiative, Oldman Watershed Council and Government of Alberta, Edmonton, 2005.

[19] Reader's Digest, Do you think agricultural runoff threatens our health? 2005, http://www.readersdigest.ca/debate.html?a=v\&di=123, 19-11, 2006. 
[20] Price, J. D., Murky waters: Are factory farms fouling our water? Alberta View, May/June, issue, 2003.

[21] Health Canada. Notifiable diseases annual summary. Canada Communicable Disease Report, 27, pp. 2765, 2001.

[22] Gannon, V. P. J., Graham, T. A., Read, S., Ziebell, K., Muckle, A., Mori, J., Thomas, J., Selinger, B., Townshend, I. \& Byrne, J., Bacterial pathogens in southern Alberta, Canada, Journal of Toxicology and Environmental Health Part A, 67, pp. 1643-1653.

[23] Wing, S., Freedman, S. \& Band, L., The potential impact of flooding on confined animal feeding operations in Eastern North Carolina, Environmental Health Perspectives, 110(4), pp. 387-391, 2002.

[24] Ahern, M., Kovats, R. S., Wilkinson, P., Roger, F. \& Matthies, F., Global health impacts of floods: Epidemiologic evidence, Epidemiologic Reviews, 27, pp. 36-46, 2005.

[25] Alberta Agriculture, Food and Rural Development, Manure management for cow/calf producers: What is required by the Agricultural Operation Practices Act (AOPA), Government of Alberta, Edmonton, Alberta, 2005.

[26] Kassem, A., McRae, T. \& Sydor, M., Integrated water resources management, OECD Workshop on Agriculture and water: Sustainability, markets and policies held between 17-18 November in Barmera, South Australia, 2005. 